УДК 811.161 .1

DOI: $10.17223 / 22274200 / 17 / 9$

\title{
М.В. Пименова
}

\section{ЛЕКСИКОГРАФИЧЕСКОЕ ОПИСАНИЕ ДРЕВНЕРУССКИХ УСТОЙЧИВЫХ СОЧЕТАНИЙ СЛОВ (НА МАТЕРИАЛЕ ГЛАГОЛЬНЫХ ОБОРОТОВ)}

Обсуждаются перспективы создания специального словаря древнерусских устойчивых сочетаний слов на материале одного из видов подобных единичоборотов с глагольным стержневым компонентом. Рассматриваются их структурные модели: ядерная (глагол + существительное в винительном падеже) и периферийные. Представляется синкретичная семантика данных оборотов: 'ритуальное действие, направленное на объект + результат'. Демонстрируются принципы описания устойчивых глагольных оборотов в исторических словарях $X I X-X X I$ вв.

Ключевые слова: лексикография, исторические словари, диахрония, устойчивые сочетания слов, глагольный стержневой компонент.

Исследователи отмечают, что «за последнее время создано более ста специальных фразеологических словарей разных типов» [1. C. 437], среди которых толковые, этимологические, диалектные, идеографические, аспектные (словари фразеологических синонимов, устойчивых сравнений, паремий, перифраз, трансформаций / варьирования, окказиональных ФЕ) и др. [2. С. 486-529]. Диахронический аспект изучения устойчивых сочетаний слов «...долгое время оставался в тени синхронных исследований, и не удивительно поэтому, что историческая фразеология до сих пор находится на начальной стадии развития» [1. С. 454].

В книге «История русской лексикографии» В.М. Мокиенко и Т.Г. Никитина указывают на «единственный исторический фразеологический словарь, точнее, “Материалы для фразеологического словаря XVIII в.” М.Ф. Палевской (1980)» [1. С. 454], который «...носит экспериментальный характер и не претендует на полный охват фразеологического состава русского языка описываемого периода» [1. С. 454]. Л.А. Ивашко в учебнике «Лексикография русского языка» (раздел «Исторические фразеологические словари») приводит описание также только этого словаря [2. С. 512-513]. В 2011 г. вышел в свет толково-энциклопедический «Фразеологический словарь старо- 
славянского языка», содержащий свыше 500 устойчивых лексикосемантических единиц «первого литературного языка славян» [3. С. 6] (подробнее см.: [4]). Что касается лексикографического описания древнерусских устойчивых сочетаний слов донациональной эпохи (XI-XVII вв.), то оно, насколько нам известно, не предпринималось, хотя «идиомы и устойчивые обороты всегда включались составителями в толковые словари русского языка» [5. С. 71]. По мнению исследователей, «...начало более или менее регулярной словарной фиксации устойчивых словосочетаний (УС) фразеологического характера следует связывать с Азбуковниками XVI-XVII вв. - сборниками языковедческой направленности, объединившими предшествующие словарные материалы и новые опыты лексикографического анализа библейских текстов, учительской литературы, патериков, житий и т.п.» [1. C. 440].

Изучение в древнерусских текстах устойчивых сочетаний слов «...с особым значением, не сводящимся к обычному значению его компонентов», как отмечает Б.А. Ларин, началось еще в XIX в. [6. C. 129]. Для этих лексико-семантических единиц исследователи использовали самые разнообразные термины, среди которых как $ф p a-$ зеологизмы [3; 6. С. 148; 7; 8. С. 118-141; 9; 10. С. 163-174; 11], так и номинации, имплицитно указывающие на их «особость» по сравнению с современными ФЕ: неизменные выражения (В.О. Ключевский) [12. С. 63], застывише сочетания (А.М. Пешковский) [13. С. 263], словесные формульл (Д.С. Лихачев) [14. С. 81], устойчивые словесныле комплексы (А.Г. Ломов) [15], формуль-синтагмы (В.В. Колесов) [16. С. 137-138], коллокациии (Е.М. Верещагин) [17. С. 19-21], фихуры (figurae) (Р. Пиккио) [18. С. 38, 483] и др. (см. также [19. С. 52]). Конечно, данные термины могут иметь право на существование, но все они используются в отрыве от лингвистической терминологической системы.

Мы для обозначения устойчивых лексико-семантических единиц в диахронии предложили термин синкретемы [19. С. 52-53; 20. C. 249], корень которого выражает значение, указывающее на особенности ментальности донациональной эпохи, а суффикс - на ряд эмических единиц различных языковых уровней: синкрет- (ср.: синкретизм - слитность мировосприятия, нерасчлененность чувственного созерцания и абстрактной деятельности мышления; синкрета - минимальная единица древнего текста; синкретсемия - лексико- 
семантическая категория, объединяющая случаи выражения синкретичного значения) + -ем-а (ср.: фонема, морфема, морфонема, лексема, семема, синтаксема, фразема и т.д.). Отличительной чертой синкретем на фоне современных ФЕ является синкретичное значение, отражающее древнюю концептуальную форму русской ментальности - ментализацию (XI-XIV вв.), связанную с метонимией [21. C. 13-14] (а не с метафорой, как большинство современных ФЕ).

Основанные на смежности метонимические переносы предопределяют, на наш взгляд, следующие дифференциальные признаки синкретем:

1) системность в связи с регулярностью метонимии (ср.: нерегулярность, вторичность и относительная «единичность» метафорических ФЕ);

2) синтагматический характер структурно-семантических типов синкретем в связи с построением метонимией синтагмы (ср.: метафорическая парадигма $\Phi \mathrm{E}^{1}$ );

3) разработка объема понятия, в связи с чем наблюдается преимущественная связь значения с денотатом (ср.: метафорическая разработка содержания понятия у ФЕ) [19. С. 50-58].

В своих работах мы уже обсуждали общетеоретические проблемы создания исторического словаря древнерусских устойчивых единиц [20]. Нами накоплен определенный опыт в лексикографическом описании отдельных видов синкретем: под нашим руководством защищены кандидатские диссертации, посвященные парным именованиям (радость и веселье, хл ъбъ и соль, слово и дело, гуси-лебеди, путьдорога - 349 единиц, 1230 контекстов) [23], устойчивым сравнениям (бельи аки снегъ, горекъ яко пелынь, сияти яко светило, быти яко зв қзда, стр $\mathbf{k} л ь$ аки дождь - 543 единицы, 910 контекстов) [24], сочетаниям с творительным ограничения (красенъ лицемъ, прость умомъ, одержимъ нев қриемъ, честенъ с ъдинами - 325 единиц, 1157 контекстов) [25].

В настоящее время идет работа над лексикографическим описанием ещё одного вида древнерусских синкретем - устойчивых оборотов, в которых стержневым компонентом является глагол (типа утвердити /створити любовь, ив Һлити мечи, искати славы, удари /бити челом, да"ти труды, оттрясти сон, творити молитву, учинится смерть / поруха и недобор и т.д.). Данные единицы изучались лингви-

\footnotetext{
${ }^{1}$ См., например, парадигму русской пищевой метафоры [22].
} 
стами в синхронном и диахроническом аспектах с использованием различных терминов: описательные формы глагола (Ф.И. Буслаев) [26. С. 509-511], глагольные фразеологические единицыь (А.Г. Ломов, Л.Я. Костючук) [15, 27], сочетания глагол + абстрактное существительное (М.М. Копыленко) [9], устойчивые глагольно-именные словосочетания (В.М. Дерибас) [28], описательныее глагольно-именнье обороть (П.А. Лекант, Е.Н. Лагузова) [29, 30], коллокации (Е.Г. Борисова) [31] и др. Мы используем для обозначения данного вида синкретем термин устойчивый глагольный оборот. Материалы собираются нами и нашими учениками методом сплошной выборки из памятников XI-XVII вв.: выявлено 380 устойчивых глагольных оборотов, употребленных в 526 контекстах (Остромирово евангелие, «Слово о Законе и Благодати» митрополита Илариона, «Слово о полку Игореве» [32], «Повесть временных лет», «Сказание о Борисе и Глебе», «Житие Феодосия Печерского», «Повесть о битве на Липице», памятники деловой письменности и др.).

Приведем примеры употребления устойчивых глагольных оборотов в древнерусских текстах различных типов.

Народно-литературный: «(6453) И от $m \mathbf{k} x$ заповедано обновити ветъхий миръ, и утвердити любовь межю Греки и Русью <..>

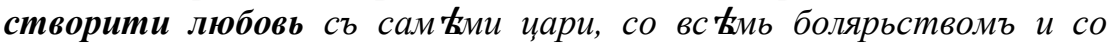
вс Һии людьми гречьскими на вся л қта» [33. Т. 1. Стлб. 47]. «О, моя сынночя, Игорю и Всеволоде! Рано еста начала Половецкую землю мечи цв 中лити, а себ т славь искати» [34. С. 382]. «И бысть вторник 4 недели, выеха Ярослав самъ из града, удари челом Константину брату» [35. С. 126].

Книжно-славянский: «Разум ъвъ же Иисус, рече имъ: "Почто труды д ъете жен 't?” [36. Л. 153]. «Въстани, о честнаа главо, от гроба твоего, въстани, оттряси сонъ» [37. С. 505]. «А самъ въл $\mathbf{6} 3$ въ иатьрь свои начать мълитву творити вечернюю» [38. С. 284].

Деловой: «Црю гсдрю і великоми князю Алекһю Михаиловичю всеа Великия и Малья и Б қлья Росиі самодержьизи бьют челом $і$ извешиают сироты твоі Шуи посади земъскоі старостишко Сенка Ликоянов... с таварышии <...> И биде гсдрь ему голов $\mathbf{6}$ от тово воеводскова бою учинится смерть а на криюеечном двор твоем великого гсдря денежноі казн ъучинится поруха и недобор» [39. С. 190]. 
Следует отметить, что устойчивые глагольные обороты образованы по нескольким структурным моделям. Ядерной и самой воспроизводимой является модель «глагол + существительное в винительном падеже». Образованные по этой модели единицы, как правило, выражают следующее значение: 'произвести / производить действие по значению существительного / прямого дополнения' (действие, направленное на объект, являющийся одновременно и его результатом). Например: взять волю, взяти рать, взяти / одержати победу, възложити в қнецъ, възложити чьсть, вознести гласъ, восприяти величество, дати мудрость, дати суд, даровати прозьрение, дьржати ключь, дьржати "зыкъ, заградити уста, избыть болезнь, им $\mathbf{k} т и$ любовь, источити слезы, отворити ворота, приклонити ухо, приносити молитву, прилћпи срьдче, пролити кровь, при"ти в всть, сътворити гр $\mathbf{k} x \mathbf{b}$, сътворити миръ, творити вр $\mathbf{b} ы$, творити память / поминанье, творити труды, творити чюдо / знамение, иъ $\mathbf{k} л о-$ вати крьсть, "ти в вру и др.

Среди периферийных и непродуктивных структурных моделей можно выделить следующие (приводим их в порядке частотности):

a) «глагол + предлог + существительное в винительном падеже»: быти / ставити в версту, бити (въ) прьси, въпасти въ гр $\mathbf{k} х ъ$, возложити на умь / разумъ, въс ъсти на конь, подразити (под) нози;

б) «глагол + существительное в творительном падеже»: бити челом, бити "зыкъмъ, глазами покывати, костию пасти, украсити иконами/золотом;

в) «глагол + (предлог) + существительное в дательном падеже»: бити по рукамъ, разумети книгам, предати съмьрти, преставитися $\kappa$ Богу;

г) «глагол + существительное в родительном падеже»: възнести до облакъ / облака, выдавати без суда;

д) «глагол + существительное в предложном падеже»: дьржати въ оум $\mathbf{k}$, говорити в срьдие (своем) и др.

Особенностью семантики большинства устойчивых глагольных оборотов является то, что они связаны с особым денотатом, который условно можно определить как «раздваивающийся»: действие (глагол) + объект действия, совпадающий с его результатом (существительное). Наличие «раздвоения» становится особенно наглядным при сопоставлении устойчивого глагольного оборота с одной лексической единицей, которой его можно заменить фактически без какого-либо 
изменения значения: бити въ прьси - раскаиваться, бити по рукам договариваться, бити челом - просить (жаловаться), бити "зыкъмь ругать, взяти /створити победу - победить, возложити на умъ внушить, вознести глась - заговорить, восприяти величество - зазнаться, въдати доушоу - умереть, въздати дльгъ - расплатиться, възложити в қнецъ - венчать, възложити чьсть - чествовать, възяти /сътворити мирь - (по)мириться, въпасти въ

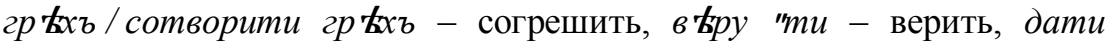
судъ - судить, дьржати въ оум - помнить, дьржати "зыкъ - молчать, изгонити бъcbl - исцелить, источити / испустити слезы (за)плакать, любы деяти - любить, отворити ворота - сдаться, отътрясати / отьтрясти сонъ - проснуться / воскреснуть, преставитися к богу - умереть, приклонити ухо - прислушаться, прил tпи срьдие (свое) - полюбить, творити / приносити молитвь - молиться, учинится съмьрть - умереть, съмьрти предати - убить и под.

При синхронном описании современного русского языка похожие (но не идентичные) случаи ученые обозначают терминами «дополнение результата» (он построил дом, она рисует иветь - О. Есперсен [40. С. 181-182]), «винительный результата» (строить дом, иить платье - А.М. Пешковский [13. С. 262]), «двусмысленность» и «синкретизм при выражении валентностей» (убираться в комнате: 'место' + 'объект' - Ю.Д. Апресян [41. С. 140, 180-181, 186]) и др. (см. также: [42. С. 29]).

С подобными сочетаниями устойчивые глагольные обороты объединяет общая структура (глагол + существительное) и синкретизм (нерасчлененность) семантики (объект + результат и др.), а отличает - наличие устойчивости и воспроизводимости модели, «раздвоение» денотата (которое можно выявить при помощи трансформации словосочетания), абстрактность, а не конкретность, семантики. Кроме того, в древнерусском тексте бытование устойчивых глагольных оборотов было поддержано существованием ритуальных действий. Например, возложение венца при вступлении на престол (венчать на царство), целование креста при принятии присяги на

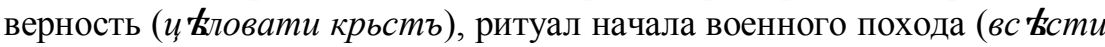
на конь), клятва землёй (положити ряд) и др. Так, О.П. Лопутько пишет: «В договорах русских с греками 911 года употреблено выражение положити ряд ('заключить договор'), являющееся характерным для древнерусских памятников различных жанров. Однако истоки 
его, несомненно, находятся в устной традиции обычного права восточных славян, о чем свидетельствует связь данной устойчивой формулы с весьма архаичным ритуалом клятвы землей. Более того, в древнерусских текстах старшего периода различных жанров - не только деловых - появляется вполне четкая система формул, связанных со всем комплексом ритуалов, которые регулировали отношения в данной культурной области <...> Далее мы приводим основные элементы системы формул, восходящих к ритуалу клятвы землей... Положстти ряд, сотворити рядъ ('заключить договор'), възвести на рядъ ('официально ввести в должность с осуществлением подобающего обряда'), стояти въ ряду ('соблюдать условия договора'), nоuти на рядъ ('вступить в переговоры'), съступити ряду, переступити рядъ ('нарушить договор'), раздьрати рядъ ('нарушить общественное согласие')» [43. С. 79-80].

Как уже отмечалось, специального словаря древнерусских устойчивых сочетаний слов, в том числе глагольных оборотов, не существует, однако в исторических толковых словарях наблюдается фиксация данных единиц, правда, не системная, а спорадическая.

В «Материалах для словаря древнерусского языка по письменным памятникам» И.И. Срезневского «устойчивые словосочетания... приводятся после толкования значения заголовочного слова в качестве иллюстраций к нему» [1. С. 440]. Приведем примеры иллюстраций, включающих устойчивые глагольные обороты: «Аже Смолнянинъ... не росплативъся поид ть къ Богови, а кто его задьницю възьметъ, $m$ мъ и гостиньи тъваръ дасть». Смол. гр. п. 1230 г. (Срезн. Т. І. Стлб. 138); «И сроубиша новгородичи городъ новъ. а с Литвою миръ взяша». Новг. І л. 6706 г. (Срезн. Т. ІІ. Стлб. 150); «Сльииав же владыка Семеонъ особую рать промежи своими д ттми и испусти слезы изъ очию». Новг. І л. 6926 г. (Срезн. Т. ІІІ. Стлб. 438).

В «Словаре-справочнике “Слова о полку Игореве"» текст самого известного памятника Древней Руси рассматривается «...на фоне словарного состава древнерусского языка XI-XVII вв.» (Сл.-Спр. Вып. 6. C. 6), в который включены и устойчивые единицы, в том числе глагольные. Например: « Творити мирь - заключать мирный договор,

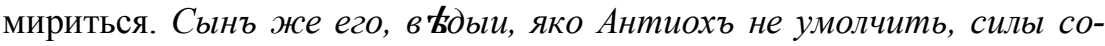
браме земныя, с римляны миръ творяше. Флав. Полон. Иерус., 168 (XVI в. нач. XII в.). 980: И рече Блудъ Ярополку: Видиши, колько войн у брата твоего? Нама ихъ не перебороти. Твори миръ съ бра- 
томъ своимъ. Пов. врем. лет, 55 (1377 нач. XII в.). Творити чюдо (знамение). И рече ему: Равви, ...никъто же бо не можеть знамении сихъ творити, яже ты твориши. Остр. ев., 7об. (1056-1057 гг.). Чюдо творить творьць, судиму ти, отьче: блудьна бо жена, стрьмлениемь ята бъсовьскыимь, вс қиь являше тя чиста, Григорие. Мин. нояб., 444 (1097 г.)» (Сл.-Спр. Вып. 6. С. 13).

В «Словаре русского языка XI-XVII вв.», как указывают исследователи, «существенно увеличен объем фразеологического материала», причем устойчивые сочетания слов отграничиваются от словарной статьи заголовочного слова при помощи специального знака $(\diamond)$, хотя эти обороты не дифференцируются [1. С. 442]. Например: « $\diamond$ Бити по рукамъ - договариваться, заключать торговую сделку. И они, головы, на томь съ ними договорилися, что имъ руки подавати, что ихъ не побить и выпустить ихъ съ женами, и съ д ттьми, и с ихъ животы, и на томъ слов с съ ними били по рукам. АМГ I, 403. 1632 г. Он Мишка рыбу сторговал купил и по рукам бил. Якут. а., карт. 1, № 1, сст. 394, 1640 г.» (СлРЯ. Вып. 1. С. 188); «॰ Возложити на сердц' (въ сердцъ), на умъ (на разумъ) - внушить кому-л. какие-л. мысли, чувства. (1051): По сем же возложи б_в князю въ ср_дце, постави его [Илариона] митрополитомъ сm_tи Софьи. Ипат. лет., 144. И се пр қже реченыи онъ боляринъ, б_у ему възложьшю на умъ, се бо напълнивъ три возы брашьна, хл \$бъ и сыръ и рыбъ... и то посъла къ блаженому въ манастырь. Ж. Феодос. Нест., 75. ХІІ ок. 1088 г.» (СлРЯ. Вып. 2. С. 293).

Словарь «Лексика и фразеология “Моления" Даниила Заточника», «...содержащий элементы разговорной речи и церковнославянизмы, цитаты из Библии и образные народные изречения, особенно ценен как источник материала для историков фразеологии. Большое количество устойчивых сочетаний, находящихся на разной стадии фразеологизации, вошли в ЛФМ. Под знаком $\triangle$ в конце словарных статей даются идиомы с четким графическим оформлением вариантности, толкованиями различным типов, указаниями на ситуации употребления» [1. С. 441]. Примеры фиксации устойчивых глагольных оборотов: «Восприяти величество. Возомнить о себе, зазнаться. Аще ли буду богат, то гордость восприиму и величество, аще ли буду убог, то помыиляю на татбу и на разбои ПВ сердце свое кому, к кому. Полюбить, привязаться. Мужа мудра обр tть, глаголи к нему и тому прил ъии сердце свое (ср. Иис. Сир. 
VI. 35) УЧ НК $35 »$ (ЛФМ. С. 160-161).

В Предисловии к «Словарю древнерусского языка XI-XIV вв.» отмечается, что «к фразеологическим единицам в Словаре относятся раздельно оформленные языковые единицы (т.е. состоящие из двух или более слов), имеющие целостное значение или фразеологически связанное значение одного из компонентов. Фразеологические единицы выделяются одним чёрным ромбом (\$) в конце значения или двумя ромбами в конце статьи $(\diamond \downarrow)$, если трудно установить, к какому значению ФЕ относится» (СлДРЯ. Т. І. С. 13). Например: « "зыкъмъ бити - ругать, поносить: шоставивъ же ювлоги" великыи антонии. нача "зыкъм⿰ бити раслабленаго. не достоин $\mathbf{z}$ нбси и земл\# ... как сменши на х(с)а тако извещяати. ПрЛ ХІІІ, 14г.»; « ц中ловати крьсть на (чем-л.), къ (кому-л.) - присягать, давать клятву: на техъ же грамотахъ целоваль есмь крестъ. а се мо" печать. Гр 1229, сп. В (смол.)» (СлДРЯ. Т. IV. С. 317).

В «Словаре обиходного языка Московской Руси XVI-XVII вв.», как отмечают О.С. Мжельская и С.Св. Волков, устойчивые единицы представлены в соответствии с классификацией Б.А. Ларина: «... в лексикографическом описании различаются три типа устойчивых оборотов, выделяемых в словарной статье знаками ромба, треугольника и угла. Идиомы, значение которых не мотивировано значениями входящих в словосочетание слов, даются со знаком $\diamond$. Фразеологизмы с мотивированным значением отделяются знаком $\triangle$. Устойчивые словосочетания - знаком >» (СлОЯМР. Вып. 1. С. 14). Устойчивые глагольные обороты в СлОЯМР фиксируются, как правило, под знаком $>$, однако встречается и их обозначение при помощи $\triangle$, например: «> Взять под руки кого. Оказать кому-л. почет, уважение, провожая куда-л. А как Иван с судна вышел, и Сеферя взял Ивана под руки и проводили его в судебню перед городными вороты. Ст. сп. Новосильцева, 64, 1570 г. < ..>> Взять волю. Поступать по своему же-

${ }^{1}$ В цитатах из словаря «Лексика и фразеология “Моления” Даниила Заточника» содержатся указания на следующие списки и редакции памятника (нижний индекс обозначает параграф текста): ПВ 6 - список Погодина, список Владимирского музея (переделка I редакции); УЧ 53 - список Ундольского, Чудиновский список (II редакция); Сл 37 - список Соловецкого монастыря (1-я переделка II редакции); НК 35 - список Никольского (1-я переделка II редакции) (ЛФМ. С. 231). 
ланию, не считаясь ни с кем. Смиряйте их [раскольников], потому: буде не смирите и возьмут волю никакого добра не ждите от них, потому что воры, которые были с Стенькою, оне суть большая часть, которые делают нынешние мятежи. РД ІІІ, 387, 1688 г. Богъ воленъ да жена коли волю взяла. Сим. Послов., 84. XVII в.» (СлОЯМР. Вып. 2. С. 171, 333-334); « $\triangle$ Снять голову кому. Строго наказать кого-л. И какъ пришель стр қлець Оська къ мужику къ

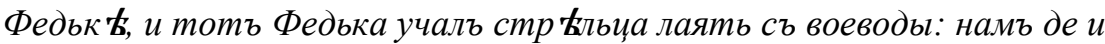
государь сталь пуще Лисовскаго, и Лисовский де мн қ головы так не сняль, какъ государь. СиД, 6, 1616 г.» (СлОЯМР. Вып. 4. С. 139).

Обобщая особенности представления устойчивых глагольных оборотов в исторических словарях XIX-XXI вв., необходимо отметить следующие изменения: а) Срезн.: использование в составе иллюстраций; б) Сл.-Спр., СлРЯ, ЛФМ, СлДРЯ: недифференцированное выделение в словарных статьях; в) СлОЯМР: разделение данных единиц на устойчивые словосочетания и фразеологизмы с мотивированным значением. Подобная дифференциация, в основу которой положен критерий степени семантической спаянности компонентов, на наш взгляд, не совсем корректна по отношению к древнерусскому материалу, поскольку, не имея объективных алгоритмов, опирается на языковое чутье исследователей-лексикографов, носителей современного русского языка, что может приводить к искажению средневековой языковой картины мира. Мы полагаем, что целесообразнее учитывать более объективные (количественные) критерии - частотность и воспроизводимость устойчивых глагольных оборотов в древнерусских текстах.

Безусловно, вопросы дифференциации устойчивых сочетаний слов в диахронии требуют дальнейшего изучения и обсуждения, а для их лексикографического описания необходимо решить еще целый ряд проблем, связанных с алгоритмом вычленения данных единиц, критериями отграничения от свободных словосочетаний и смежных видов семантических сближений, принципами расположения в историческом словаре, особенностями представления семантики, структуры, варьирования и т.д.

\section{Список условных сокращений}

ЛФМ - Лексика и фразеология «Моления» Даниила Заточника / под ред. Е.М. Иссерлин, С.С. Волкова, В.П. Фелицыной. Л. : Изд-во ЛГУ, 1981. 232 с. 
СлДРЯ - Словарь древнерусского языка (XI-XIV вв.). М. : Рус. яз. ; Азбуковник, 1988-2016. Т. I-ХI. Издание продолжается.

СлОЯМР - Словарь обиходного русского языка Московской Руси XVIXVII вв. СПб. : Наука, 2004-2018. Вып. 1-8. Издание продолжается.

СлРЯ - Словарь русского языка XI-XVII вв. М. ; СПб. : Наука ; Азбуковник: Нестор-История, 1975-2015. Вып. 1-30. Издание продолжается.

Сл.-Спр. - Словарь-справочник «Слова о полку Игореве» / сост. В.А. Виноградова; под ред. Б.Л. Богородского, Д.С. Лихачева, О.В. Творогова. Л. : Наука, 1965-1984. Вып. 1-6.

Срезн. - Срезневский И.И. Материалы для словаря древнерусского языка. СПб.: Типография Императорской Академии наук, 1893-1912. Т. 1-3.

\section{Литература}

1. История русской лексикографии / под ред. Ф.П. Сороколетова. СПб. : Наука, 1998. 610 с.

2. Лексикография русского языка / под ред. Д.М. Поцепни. СПб. : Факультет филологии и искусств СПбГУ, 2009. 672 с.

3. Фразеологический словарь старославянского языка / отв. ред. С.Г. Шулежкова. М. : Флинта ; Наука, 2011. 424 с.

4. Пименова М.Вас., Богрова К.М. Проблемы фразеографического описания старославянского языка // Проблемы истории, филологии, культуры. Вестник Магнитогорского государственного университета. 2011. № 3. С. 318-320.

5. Андрианова Д.В. Изменение лексикографических принципов представления фразеологизмов и устойчивых сочетаний слов в «Словаре современного русского литературного языка» и в «Большом академическом словаре русского языка» // Вопросы лексикографии. 2019. № 15. С. 71-82.

6. Ларин Б.А. История русского языка и общее языкознание. М. : Просвещение, 1977. $224 \mathrm{c}$.

7. Архангельский В.Л. Фразеология «Поучения» Владимира Мономаха в связи с общими вопросами фразеологии русского языка : автореф. дис. ... канд. филол. наук. М., $1950.16 \mathrm{c}$.

8. Виноградов В.В. Лексикология и лексикография / под ред. В.Г. Костомарова. М. : Наука, 1977. 312 с.

9. Копыленко М.М. Исследование в области славянской фразеологии древнейшей поры : автореф. дис. ... д-ра филол. наук. Л., 1967. 47 с.

10. Мокиенко В.М. Славянская фразеология. М. : Высшая школа, 1980. 207 с.

11. Толстой Н.И. Дополнительные суждения о реконструкции праславянской фразеологии // Славянское и балканское языкознание. Проблемы лексикологии и семантики. Слово в контексте культуры / под ред. Г.К. Венедиктова. М. : Индрик, 1999. C. $47-63$.

12. Ключевский В.О. Древнерусские жития святых как исторический источник. М. : Наука, 1989. 512 с. (репринтное издание 1871 года).

13. Пешковский А.М. Русский синтаксис в научном освещении. 5-е изд. М. : Гос. учеб.-пед. изд-во, 1935. 452 с. 
14. Лихачев Д.С. Поэтика древнерусской литературы. 3-е изд., доп. М. : Наука, 1979. $352 \mathrm{c}$.

15. Ломов А.Г. Устойчивые словесные комплексы древнейших русских летописей : автореф. дис. ... канд. филол. наук. Самарканд, 1969. 33 с.

16. Колесов В.В. Древнерусский литературный язык. Л. : Изд-во ЛГУ, 1989. $295 \mathrm{c}$.

17. Верещагин Е.М. История возникновения древнего общеславянского литературного языка. Переводческая деятельность Кирилла и Мефодия. М. : Мартис, 1997. $315 \mathrm{c}$.

18. Пиккио P. Slavia Orthodoxa: Литература и язык / отв. ред. Н.Н. Запольская. М. : Знак, 2003. $720 \mathrm{c}$.

19. Пименова М.Вас. Красотою украси: выражение эстетической оценки в древнерусском тексте. Санкт-Петербург : Филологический факультет СПбГУ ; Владимир : ВГПУ, 2007. 415 с. (Филологические исследования).

20. Пименова М.Вас. Проблемы создания словаря устойчивых единиц в диахронии: язык и ментальность // Русский язык в поликультурном мире / отв. ред. Е.Я. Титаренко. Симферополь : Типография «АРИАЛ», 2018. Т. 1. С. 248-254.

21. Колесов В.В. История русского языка. СПб. : Филологический факультет СПбГУ ; М. : Академия, 2005. 672 с.

22. Словарь русской пищевой метафоры / сост. А.В. Боровкова, М.В. Грекова, Н.А. Живаго, Е.А. Юрина ; под ред. Е.А. Юриной. Томск : Изд-во Том. ун-та, 2015-2017. T. 1-2.

23. Артамонова М.В. Парные именования в древнерусском тексте : дис. ... канд. филол. наук. Владимир, 2005. $171 \mathrm{c.}$

24. Богрова К.М. Устойчивые сравнения в древнерусском тексте: семантика и структура : дис. ... канд. филол. наук. Владимир, 2012. 180 с.

25. Рыкин Е.Ю. Сочетания с творительным ограничением как средство выражения оценки в древнерусском тексте : дис. ... канд. филол. наук. Владимир, 2014. $204 \mathrm{c}$.

26. Буслаев Ф.И. Историческая грамматика русского языка. М. : Учпедгиз, $1959.623 \mathrm{c}$.

27. Костючук Л.Я. Устойчивые словесные комплексы в древнерусском деловом языке (по грамотам XI-XIV вв.): структурно-грамматическая характеристика : автореф. дис. ... канд. филол. наук. Л., 1964. 22 с.

28. Дерибас В.М. Устойчивые глагольно-именные словосочетания русского языка. М. : Русский язык, 1975. 265 с.

29. Лекант П.А. Очерки по грамматике русского языка. М. : Изд-во МГОУ, 2002. $312 \mathrm{c}$.

30. Лагузова Е.Н. Описательный глагольно-именной оборот как единица номинации. М. : Изд-во МГОУ, 2003. 243 с.

31. Борисова Е.Г. Слово в тексте: словарь коллокаций (устойчивых сочетаний) русского языка с англо-русским словарем ключевых слов. М. : Филология, 1995. $149 \mathrm{c}$.

32. Константинов E.C. Устойчивые глагольные обороты в древнерусском тексте // Дни науки студентов Владимирского государственного университета 
имени Александра Григорьевича и Николая Григорьевича Столетовых. Владимир : Изд-во ВлГУ, 2019. С. 2222-2227.

33. Полное собрание русских летописей. М. : Наука, 1962. Т. 1, 2.

34. Слово о полку Игореве / подгот. текста, пер. и коммент. О.В. Творогова // Памятники литературы Древней Руси. ХІІ век. М. : Худ. лит., 1980. С. 372-387.

35. Повесть о битве на Липице / подгот. текста, пер. и коммент. Я.С. Лурье. Памятники литературы Древней Руси. ХІІІ век. М. : Художественная литература, 1981. C. $114-127$.

36. Остромирово Евангелие 1056-1057 гг. М. ; Л. : Издат. отдел Моск. Патриархата; Аврора, 1988. 294 л.

37. Митрополит Иларион. Слово о Законе и Благодати / подгот. текста и коммент. А.М. Молдована // Памятники литературы Древней Руси. XVII век. Книга третья. М. : Художественная литература, 1994. С. 583-619.

38. Сказание о Борисе и Глебе / подгот. текста, пер. и коммент. Л.А. Дмитриева // Памятники литературы Древней Руси. XI - начало XII века. М. : Худ. лит., 1978. С. 278-303.

39. Памятники деловой письменности XVII века. Владимирский край / под ред. С.И. Коткова. М. : Наука, 1984. 367 с.

40. Есперсен О. Философия грамматики. М. : Изд-во иностр. лит., 1958. 400 с.

41. Апресян Ю.Д. Лексическая семантика. Синонимические средства языка. М. : Наука, 1974. 368 с.

42. Пименова М.Вас. Лексико-семантический синкретизм как проявление формально-содержательной языковой асимметрии // Вопросы языкознания. 2011. № 3. С. $19-48$.

43. Лопутько О.П. История русского литературного языка: древнейший период. Новосибирск : Изд-во НГПУ, 2005. 189 с.

\section{Lexicographic Description of Old Russian Set Combinations of Words (On the Material of Verb Phrases)}

Voprosy leksikografii - Russian Journal of Lexicography, 2020, 17, pp. 178-194.

DOI: $10.17223 / 22274200 / 17 / 9$

Marina V. Pimenova, Vladimir State University named after Alexander and Nikolay Stoletovs (Vladimir, Russian Federation). E-mail: pimenova-vgpu@yandex.ru

Keywords: lexicography, historical dictionaries, diachrony, set combinations of words, verb component.

The aim of the article is to discuss the prospects of creating a special dictionary of old Russian set combinations of words. This dictionary would fill the existing gap in the number of hundreds of lexicographic descriptions of phraseological expressions of the modern Russian language, as well as one dictionary of the 18th century and a phraseological dictionary of the old Slavic language. The article analyzes the nominations scientists used since the 19th century to designate set combinations of words in diachrony (invariant expressions, hardened combinations of words, formulas, etc.). The author proposes the term "syncretemes" speaking about the peculiarities of the mentality of ancient times that determine the differences of these units from modern phraseol- 
ogy (from syncretism as a non-dismemberment of sensual contemplation and abstract thinking activities). The article reports about the experience the author accumulated in the lexicographic description of some types of syncretemes - paired names, set comparisons, phrases with instrumental case in the meaning of restriction. The article analyzes the set combinations of words with a verb core component (such as vzyati rat'). 380 such units, extracted by the continuous sampling method from 526 contexts of written monuments, were identified. The author considers the structure of these units built according to the following models: (a) productive and frequent "verb + noun 4 " (vzyat' volyu); (b) unproductive "verb + noun," (biti chelom), "verb + noun," (razumeti knigam), etc. The author focuses attention on the feature of syncretic semantics of these syncretemes: action directed at the object, which is simultaneously its result. The feature manifests itself in the conditional "split" of the denotate ("pobedit" - vzyati pobedu). The author compares the fixation of set verb phrases in the historical dictionaries of the 19th-21st centuries, pointing to the following changes: (1) the use of illustrative examples; (2) undifferentiated emphasis in the dictionary; (3) the separation of these units into set combinations of words and phraseological units with a motivated meaning. According to the author, such a differentiation, which is based on the criterion of the degree of the semantic cohesion of the components, is not quite correct in relation to the old Russian material because it has no objective algorithms and is based on modern researchers' feeling for language. The author proposes to take into account more objective criteria - frequency and productivity of set verb phrases in old Russian texts. In the conclusion, it is indicated that the lexicographic description of set combinations of words requires solving a number of problems related to the algorithm of detecting these units, to the criteria of separating them from free combinations of words, to the principles of locating them in the historical dictionary, to the peculiarities of presenting their semantics and structure.

\section{References}

1. Sorokoletov, F.P. (1998) Istoriya russkoy leksikografii [History of Russian Lexicography]. Saint Petersburg: Nauka.

2. Potsepnya, D.M. (ed.) (2009) Leksikografiya russkogo yazyka [Lexicography of the Russian Language]. Saint Petersburg: Saint Petersburg State University, Faculty of Arts and Philology.

3. Shulezhkova, S.G. (ed.) (2011) Frazeologicheskiy slovar' staroslavyanskogo yazyka [Phraseological Dictionary of the Old Slavonic Language]. Moscow: Flinta: Nauka.

4. Pimenova, M.V. \& Bogrova, K.M. (2011) Phraseographic presentation of Old Slavonic. Problemy istorii, filologii, kul'tury - Journal of Historical, Philological and Cultural Studies. 3. pp. 318-320. (In Russian).

5. Andrianova, D.V. (2019) The Changes in the Lexicographic Principles of Representation of Phraseological Units and Stable Word Combinations in the Dictionary of the Modern Russian Literary Language and in the Large Academic Dictionary of the Russian Language. Voprosy leksikografii - Russian Journal of Lexicography. 15. pp. 71-82. (In Russian). DOI: 10.17223/22274200/15/5 
6. Larin, B.A. (1977) Istoriya russkogo yazyka i obshchee yazykoznanie [History of the Russian Language and General Linguistics]. Moscow: Prosveshchenie.

7. Arkhangel'skiy, V.L. (1950) Frazeologiya "Poucheniya" Vladimira Monomakha $v$ svyazi s obshchimi voprosami frazeologii russkogo yazyka [Phraseology of the "Instruction" by Vladimir Monomakh in connection with general questions of the phraseology of the Russian language]. Abstract of Philology Cand. Diss. Moscow.

8. Vinogradov, V.V. (1977) Leksikologiya i leksikografiya [Lexicology and Lexicography]. Moscow: Nauka.

9. Kopylenko, M.M. (1967) Issledovanie v oblasti slavyanskoy frazeologii drevneyshey pory [Research in the field of Slavic phraseology of ancient times]. Abstract of Philology Dr. Diss. Lenigrad.

10. Mokienko, V.M. (1980) Slavyanskaya frazeologiya [Slavic Phraseology]. Moscow: Vysshaya shkola.

11. Tolstoy, N.I. (1999) Dopolnitel'nye suzhdeniya o rekonstruktsii praslavyanskoy frazeologii [Additional thoughts on the reconstruction of the Pre-Slavic phraseology]. In: Venediktov, G.K. (ed.) Slavyanskoe i balkanskoe yazykoznanie. Problemy leksikologii $i$ semantiki. Slovo v kontekste kul'tury [Slavic and Balkan Linguistics. Problems of lexicology and semantics. The word in the context of culture]. Moscow: Indrik. pp. 47-63.

12. Klyuchevskiy, V.O. (1989) Drevnerusskie zhitiya svyatykh kak istoricheskiy istochnik [Old Russian Hagiographies as a Historical Source]. Reprint of 1871 edition. Moscow: Nauka.

13. Peshkovskiy, A.M. (1935) Russkiy sintaksis v nauchnom osveshchenii [Russian Syntax In Scientific Coverage]. 5th ed. Moscow: Gosudarstvennoe uchebnopedagogicheskoe izdatel'stvo.

14. Likhachev, D.S. (1979) Poetika drevnerusskoy literatury [Poetics of Ancient Russian Literature]. 3rd ed. Moscow: Nauka.

15. Lomov, A.G. (1969) Ustoychivye slovesnye kompleksy drevneyshikh russkikh letopisey [Stable verbal complexes of the most ancient Russian chronicles]. Abstract of Philology Cand. Diss. Samarkand.

16. Kolesov, V.V. (1989) Drevnerusskiy literaturnyy yazyk [Old Russian Literary Language]. Leningrad: Leningrad State University.

17. Vereshchagin, E.M. (1997) Istoriya vozniknoveniya drevnego obshcheslavyanskogo literaturnogo yazyka. Perevodcheskaya deyatel'nost' Kirilla $i$ Mefodiya [The History of the Emergence of the Ancient Slavonic Literary Language. Translation activities of Cyril and Methodius]. Moscow: Martis.

18. Picchio, R. (2003) Slavia Orthodoxa: Literatura i yazyk [Slavia Orthodoxa: Literature and language]. Moscow: Znak.

19. Pimenova, M.V. (2007) Krasotoyu ukrasi: vyrazhenie esteticheskoy otsenki v drevnerusskom tekste [Krasotoyu Ukrasi: An expression of aesthetic evaluation in the Old Russian text]. Saint Petersburg: Saint Petersburg State University, Faculty of Philology; Vladimir: Vladimir State Pedagogical University.

20. Pimenova, M.V. (2018) Problemy sozdaniya slovarya ustoychivykh edinits v diakhronii: yazyk i mental'nost' [Problems of creating a dictionary of stable units in diachrony: language and mentality]. In: Titarenko, E.Ya. (ed.) Russkiy yazyk $v$ 
polikul'turnom mire [Russian Language in the Multicultural World]. Vol. 1. Simferopol: OOO "Izd-vo Tipografiya “ARIAL"”. pp. 248-254.

21. Kolesov, V.V. (2005) Istoriya russkogo yazyka [History of the Russian Language]. Saint Petersburg: Saint Petersburg State University, Faculty of Philology; Moscow: Akademiya.

22. Yurina, E.A. (ed.) (2015-2017) Slovar' russkoy pishchevoy metafory [Dictionary of the Russian Food Metaphor]. Vols 1-2. Tomsk: Tomsk State University.

23. Artamonova, M.V. (2005) Parnye imenovaniya v drevnerusskom tekste [Paired naming in the Old Russian text]. Philology Cand. Diss. Vladimir.

24. Bogrova, K.M. (2012) Ustoychivye sravneniya $v$ drevnerusskom tekste: semantika i struktura [Stable comparisons in the Old Russian text: semantics and structure]. Philology Cand. Diss. Vladimir.

25. Rykin, E.Yu. (2014) Sochetaniya s tvoritel'nym ogranicheniya kak sredstvo vyrazheniya otsenki $v$ drevnerusskom tekste [Combinations with the instrumental restrictive case as a means of expressing evaluation in the Old Russian text]. Philology Cand. Diss. Vladimir.

26. Buslaev, F.I. (1959) Istoricheskaya grammatika russkogo yazyka [Historical Grammar of the Russian Language]. Moscow: Uchpedgiz.

27. Kostyuchuk, L.Ya. (1964) Ustoychivye slovesnye kompleksy v drevnerusskom delovom yazyke (po gramotam XI-XIV vv.): strukturno-grammaticheskaya kharakteristika [Stable verbal complexes in the Old Russian business language (according to the letters of the 11th-14th centuries): structural and grammatical characteristic]. Abstract of Philology Cand. Diss. Leningrad.

28. Deribas, V.M. (1975) Ustoychivye glagol'no-imennye slovosochetaniya russkogo yazyka [Stable Verb-Noun Phrases of the Russian Language]. Moscow: Russkiy yazyk.

29. Lekant, P.A. (2002) Ocherki po grammatike russkogo yazyka [Essays on the Grammar of the Russian Language]. Moscow: Moscow Region State University.

30. Laguzova, E.N. (2003) Opisatel'nyy glagol'no-imennoy oborot kak edinitsa nominatsii [Descriptive Verb-Noun Phrase as a Unit of Nomination]. Moscow: Moscow Region State University.

31. Borisova, E.G. (1995) Slovo v tekste: slovar' kollokatsiy (ustoychivykh sochetaniy) russkogo yazyka s anglo-russkim slovarem klyuchevykh slov [Word in the Text: Dictionary of collocations (stable combinations) of the Russian language with the English-Russian dictionary of keywords]. Moscow: Filologiya.

32. Konstantinov, E.S. (2019) [Stable verb phrases in the Old Russian text]. Dni nauki studentov Vladimirskogo gosudarstvennogo universiteta imeni Aleksandra Grigor'evicha i Nikolaya Grigor'evicha Stoletovykh [Student Science Days of Vladimir State University named after Alexander and Nikolay Stoletovs]. Proceedings of the Conferences. Vladimir. 18 March - 5 April 2019. Vladimir: Vladimir State University. pp. 2222-2227. (In Russian).

33. Karskiy, I.F. \& Shakhmatov, A.A. (1962) Polnoe sobranie russkikh letopisey [Complete Collection of Russian Chronicles]. Vols 1-2. Moscow: Nauka.

34. Tvorogov, O.V. (ed.) (1980) Slovo o polku Igoreve [The Tale of Igor's Campaign]. In: Dmitriev, L.A. \& Likhachev, D.S. (eds) Pamyatniki literatury Drevney Rusi. 
XII vek [Literary Monuments of Ancient Russia. 12th century]. Moscow: Khudozhestvennaya literatura. pp. 372-387.

35. Lur'e, Ya.S. (ed.) (1981) Povest' o bitve na Lipitse [The story of the battle of Lipica]. In: Dmitriev, L.A. \& Likhachev, D.S. (eds) Pamyatniki literatury Drevney Rusi. XIII vek [Literary Monuments of Ancient Russia. 13th century]. Moscow: Khudozhestvennaya literatura. pp. 114-127.

36. Anon. (1988) Ostromirovo Evangelie 1056-1057 gg. [Ostromir Gospels, 10561057]. Moscow: Izdatel'skiy otdel Moskovskogo Patriarkhata; Leningrad: "Avrora”.

37. Metropolitan Hilarion. (ed.) (1994) Slovo o Zakone i Blagodati [Sermon on Law and Grace]. In: Dmitriev, L.A. \& Likhachev, D.S. (eds) Pamyatniki literatury Drevney Rusi. XVII vek [Literary Monuments of Ancient Russia. 17th century]. Vol. 3. Moscow: Khudozhestvennaya literatura. pp. 583-619.

38. Dmitriev, L.A. (ed.) (1978) Skazanie o Borise i Glebe [The Tale of Boris and Gleb]. In: Dmitriev, L.A. \& Likhachev, D.S. (eds) Pamyatniki literatury Drevney Rusi. XI - nachalo XII veka. [Literary Monuments of Ancient Russia. 11th - early 12th century]. Moscow: Khudozhestvennaya literatura. pp. 278-303.

39. Kotkov, S.I. (ed.) (1984) Pamyatniki delovoy pis'mennosti XVII veka. Vladimirskiy kray [Monuments of Business Writing of the 17th Century]. Moscow: Nauka.

40. Jespersen, O. (1958) Filosofiya grammatiki [The Philosophy of Grammar]. Translated from English. Moscow: Izd-vo inostrannoy literatury.

41. Apresyan, Yu.D. (1974) Leksicheskaya semantika. Sinonimicheskie sredstva yazyka [Lexical Semantics. Synonymous Means of Language]. Moscow: Nauka.

42. Pimenova, M.V. (2011) Syncretism in lexical semantics manifesting the linguistic asymmetry between form and meaning. Voprosy yazykoznaniya. 3. pp. 19-48. (In Russian).

43. Loput'ko, O.P. (2005) Istoriya russkogo literaturnogo yazyka: drevneyshiy period [History of the Russian Standard Language: The earliest period]. Novosibirsk: Novosibirsk State Pedagogical University. 